\title{
PENGARUH TERAPI KELOMPOK SUPORTIF UNTUK MENINGKATKAN OPTIMISME PADA PASIEN GAGAL GINJAL KRONIK YANG MENJALANI HEMODIALISIS
}

\author{
Salma Dias Saraswati ${ }^{1}$ \\ Yayi Suryo Prabandari \\ Rr. Indahria Sulistyarini
}

\author{
Program Studi Psikologi Profesi (S2), Universitas Islam Indonesia, Yogyakarta
}

\begin{abstract}
This research aims to observe the effectiveness of supportive group therapy to improve the optimism of patients with chronic renal failure undergoing the hemodialysis. The subject was divided into the experimental group $(n=4)$ and control group $(n=4)$. The research design was pretest post- test control group and was measured by three times (pre-test, posttest and follow-up for two weeks). Life Orientation Test (LOT-R) developed by Scheier and Carver (1985) was the measurement tools used to measure the optimism. The training module was arranged based upon the supportive group theory by van den Heuvel, et al (2002). The results showed that the subject in the experimental group had a significant increase in the optimism score in comparison to the control group that was given no supportive group therapy. The implication and limitation in the research finding would be the discussion.
\end{abstract}

Keywords: optimism, hemodyalisis patients, supportive group therapy

\begin{abstract}
ABSTRAK. Penelitian ini dilakukan untuk melihat efektivitas terapi kelompk suportif untuk meningkatkan optimism pasien gagal ginjal kronis yang menjalani hemodialisis. Pasien hemodialisis terlibat dalam penelitian ini. Subjek terbagi menjadi kelompok eksperimen $(n=4)$ dan kelompok control $(n=4)$. Rancangan penelitian yang digunakan adalah pre-test post- test control group design dan diukur sebanyak tiga kali (prates, pasca tes, dan tindak lanjut selama dua minggu). Alat ukur yang digunakan untuk mengukur optimisme adalah Life Orientation Test (LOT-R) dikembangkan oleh Scheier dan Carver (1985). Modul pelatihan disusun berdasarkan teori kelompok suportif oleh van den Heuvel, dkk (2002). Hasil menunjukkan bahwa subjek yang berada pada kelompok eksperimen menunjukkan peningkatan skor optimisme yang signifikan dibandingan dengan kelompok kontrol yang tidak mendapatkan terapi kelompok suportif. Implikasi dan keterbatasan dalam temuan penelitian kemudian akan menjadi pembahasan.
\end{abstract}

Kata kunci : optimisme, pasien hemodialisis, terapi kelompok suportif

${ }^{1}$ Korespondensi mengenai artikel dapat melalui: salmadiass@gmail.com 
Ginjal adalah salah satu organ yang penting bagi manusia. Menurut The National Kidney Disease Education Program/NKDEP (2014), ginjal memiliki fungsi untuk mengatur mineral, komposisi dan volume darah dalam tubuh, membuang hasil limbah metabolisme dalam urin dan menyerap kembali zat-zat yang masih dibutuhkan oleh tubuh, mengaktifkan vitamin $\mathrm{D}$ yang diperlukan untuk penyerapan kalsium dan menghasilkan enzim yang diperlukan untuk menghasilkan sel darah merah, serta membantu mengontrol keseimbangan asam atau basa dalam tubuh. Penurunan fungsi ginjal menyebabkan metabolisme tubuh individu terganggu. Apabila penurunan fungsi ginjal ini terjadi dalam jangka waktu yang lama dan progresif, maka akan menyebabkan terjadinya gagal ginjal kronis (Chang, Daly \& Elliot, 2010). Gagal ginjal kronis ini tentu mempengaruhi kesehatan seseorang, seperti mengalami kelelahan, kehilangan nafsu makan, dan kaki kram. Masalah-masalah umum lain yang disebabkan gagal ginjal antara lain adalah gatal, tidur bermasalah, kaki gelisah, tulang lemah, sendi bermasalah, hingga depresi (NIDDK, 2014).

Salah satu tindakan medis yang harus rutin dilakukan oleh penderita gagal ginjal kronis adalah hemodialisis (Price, 2006). Tindakan hemodialisis ini berfungsi untuk menggantikan fungsi ginjal yang rusak. Oleh karena itu, tidak salah bila penderita gagal ginjal kronis sangat tergantung dengan mesin hemodialisis seumur hidup, karena bila tidak, maka dapat membahayakan kondisi tubuhnya bahkan dapat mengakibatkan kematian (Yulianti, Rochmawati \& Purnomo, 2015).

Berdasarkan Indonesian Renal Registry (IRR) pada tahun 2016, pertumbuhan penyakit gagal ginjal kronis yang harus menjalani hemodialisis terus mengalami peningkatan setiap tahunnya. Jumlah pasien baru pada tahun 2016 mencapai lebih dari 25.446 pasien, sedangkan pada tahun 2015 sebanyak lebih dari 21.050 pasien dan pada tahun 2014 sebanyak 17.193 pasien. Mayoritas pasien gagal ginjal kronis tersebut berada pada usia 44-54 tahun.

Hemodialisis dilakukan sebanyak 1-3 kali seminggu dan setiap kalinya memerlukan waktu 2-5 jam, yang akan berlangsung terus-menerus sepanjang hidupnya, sehingga memang terapi hemodialisis yang dilakukan pasien gagal ginjal kronis menimbulkan dampak atau perubahan dari segi fisik maupun psikologis. Rahman, Rudiansyah, dan Triawanti (2013) menjelaskan bahwa gagal ginjal kronis dapat menimbulkan berbagai macam gangguan fisik dan psikologis. Perubahan fisik tersebut mengakibatkan penderita menjadi seseorang yang lemah, kurang mampu melakukan kegiatan seperti sediakala dan merasa tidak berdaya. Hampir sebagian besar penderita gagal ginjal kronis mengalami keputusasaan karena mereka merasa dirinya tidak berguna lagi karena penyakit yang dideritanya (Yulianti, Rochmawati \& Purnomo, 2015).

Selain itu, terdapat dampak psikologis lain yang ditimbulkan gagal ginjal kronis. Seidel, dkk (2014) menyatakan bahwa pasien gagal ginjal kronis sering mengalami penurunan fungsi kognitif dan gejala depresi. Banyak dari penderita gagal ginjal merasa frustrasi dan dibatasi kehidupannya seperti terkait dengan pola makan, jumlah cairan yang masuk, dan sebagainya. Safitri dan Dewi (2014) menambahkan bahwa para penderita gagal ginjal kronis merasa tidak semangat dalam menghadapi kehidupan sehari-hari, merasa putus asa dengan kondisi yang dialami dan harapan hidup yang rendah. Hal tersebut menunjukkan bahwa penderita gagal ginjal kronis memiliki sikap yang cenderung pesimis. 
Pesimisme adalah ketika individu merasa bahwa masa depannya akan buruk. Harapan yang dimiliki individu yang pesimis adalah harapan negatif yang bermakna bahwa individu merasa ragu terhadap masa depannya atau tidak memiliki kepercayaan diri (Carver \& Scheier, 2001). Individu yang pesimis, merasa bahwa dirinya tidak memiliki sumber bantuan atau dukungan yang cukup (Buchanan \& Seligman dalam Gillham, Shatte, Reivich \& Seliman, 2001).

Pesismisme sangat merugikan individu. Sebaliknya, sikap optimis memiliki banyak manfaat bagi kehidupan individu. Daraei dan Ghaderi (2012) menjelaskan bahwa optimisme adalah salah satu komponen psikologi positif yang dihubungkan dengan emosi positif dan perilaku positif yang menimbulkan kesehatan, hidup yang bebas stres, hubungan sosial dan fungsi sosial yang baik. Menurut Seligman (2006), optimisme adalah suatu pandangan yang menyeluruh, melihat hal yang baik, berpikir positif dan mudah memberikan makna bagi diri. Carver dan Scheier (1985) mendefinisikan optimisme sebagai sifat individu yang mengharapkan bahwa hal-hal baik akan terjadi di masa depan untuk membangun kepribadian yang luas.

Optimisme mampu menurunkan risiko gangguan kesehatan dan mampu membantu individu pulih lebih cepat setelah mengalami peristiwa hidup yang besar. Individu yang optimis cenderung memiliki ekspektasi yang baik atau harapan yang lebih positif. Sikap optimis membantu individu mengatasi tekanan hidupnya, menurunkan risiko sakit (Scheier, dalam Taylor, 2009), meningkatkan penerimaan diri seseorang menjadi lebih positif (Chang, 2009), memiliki kemampuan lebih baik untuk bangkit dari kesulitannya (Carver, Scheier, \& Segerstrom, 2010), memungkinkan pengubahan perilaku dan meningkatkan kegigihan dalam melaksanakan pengobatan (Rajandram, dkk., 2011). Oleh karena itu, diperlukan terapi psikologis untuk mendukung proses penyembuhan yang sudah dilakukan melalui terapi medis.

Rasa kebersamaan, diterimanya dukungan dari orang lain dan merasa tidak sendiri, penting untuk dimiliki penderita gagal ginjal kronis agar senantiasa mampu berpikir positif atau optimis terhadap dirinya dan masa depan, mendapatkan dukungan emosional dari orang lain dan memperluas jaringan (Pender, Murdaugh, \& Parsons, 2002). Individu yang mendapatkan dukungan sosial juga akan merasa bahwa dirinya dicintai, dihargai, dan menjadi bagian dari komunitas sosial (Sarafino, 2002). Adanya dukungan sosial dapat mengurangi tekanan psikologis seperti rasa malu, sedih, putus asa dan lebih merasa bersemangat dalam menjalani pengobatan. Adapun bentuk dukungan sosial yang diberikan dapat berupa perhatian dan mendengarkan keluhan-keluhan mereka (Sari, 2009).

Salah satu intervensi psikologi kepada penderita gagal ginjal kronis yang merupakan bentuk dari dukungan sosial adalah terapi kelompok suportif yang bermanafaat untuk meningkatkan optimisme penderita gagal ginjal kronis yang menjalani hemodialisis. Supportive group atau kelompok suportif adalah suatu kelompok yang memiliki permasalahan yang sama untuk saling mendukung, mengondisikan dan memberi penguatan pada kelompok, maupun per-individu dalam kelompok. Tujuan utama dari kelompok suportif adalah tercapainya kemampuan koping yang efektif terhadap masalah yang dialami. Adanya kelompok yang memiliki permasalahan yang sama memiki permasalahan yang sama dapat memberikan kesempatan bagi individu dalam kelompok untuk saling belajar dan menguatkan satu sama lain (Corey, 2010). 
Kelebihan dari terapi kelompok suportif adalah mampu memberikan fungsi terapeutik sebagai faktor dukungan, faktor keterbukaan diri dan katarsis, faktor belajar dari anggota kelompok lain serta faktorfaktor lain yang berkaitan dengan menjalin hubungan dengan orang lain dan memahami diri sendiri. Terapi kelompok suportif memfasilitasi setiap anggota kelompok untuk dapat saling berbagi informasi dan pengalaman, serta memiliki kesempatan yang sama untuk menyampaikan keluh kesah yang telah atau sedang dihadapi sebagai bentuk katarsis (Brabender, Fallon, \& Smollar, 2004).

Oleh karena itu, diperlukan terapi kelompok suportif untuk meningkatkan optimisme pasien gagal ginjal kronis yang menjalani hemodialisis. Melalui terapi kelompok suportif, pasien dapat mengekspresikan perasaan dan pikiran yang muncul terkait dengan penyakit gagal ginjal yang dideritanya ini dengan lebih nyaman karena berada dalam kelompok yang juga merupakan penderita gagal ginjal (Tabrizi, Radfar, \& Taei, 2016). Pasien juga akan memiliki pemahaman yang lebih komprehensif mengenai penyakit gagal ginjal, sehingga pada akhirnya mampu memaknai penyakitnya dan memiliki sikap yang lebih optimis yang ditunjukkan dengan memiliki harapan dan pandangan yang lebih positif mengenai masa depannya (Tabrizi, Radfar, \& Taei, 2016). Melalui terapi kelompok suportif, para pasien diharapkan dapat mengembangkan rasa berdaya terhadap diri sendiri, merasa masih dapat melakukan banyak hal dalam hidupnya, memiliki keinginan untuk bangkit atau tidak menyerah terhadap penyakitnya dan menumbuhkan perasaan berguna atau bermanfaat bagi diri sendiri maupun orang lain.

Terapi suportif dibuat untuk membantu individu penderita gagal ginjal kronis bertukar pengalaman mengenai masalah yang dihadapi dan koping yang digunakan. Dukungan kelompok seringkali memberikan tempat yang nyaman bagi anggotanya untuk mengekspresikan perasaannya, baik yang positif ataupun negatif serta kemungkinan solusinya (Videbeck, 2008). Berdasarkan penjelasan di atas, tujuan dari penelitian ini adalah untuk meningkatkan optimisme penderita gagal ginjal kronis yang menjalani hemodialisis melalui terapi kelompok suportif. Hipotesis yang diangkat dalam penelitian ini adalah terdapat peningkatan skor optimisme yang signifikan pada pasien hemodialisis setelah diberikan intervensi berupa terapi kelompok suportif dibandingkan dengan kelompok kontrol.

\section{METODE PENELITIAN}

\section{Desain penelitian}

Desain penelitian yang digunakan pada penelitian ini adalah disain penelitian kuasi eksperimen. Desain kuasi eksperimen berarti eksperimen yang dilakukan seolaholah menyerupai keadaan yang sebenarnya. Jenis desain yang digunakan dalam penelitian ini, yaitu the non-randomized control group pretest-posttest design yang berarti desain penelitian ini melakukan pembentukan kelompok yang diambil secara acak serta akan mengadakan pra-uji dan pasca-uji (Sukardi, 2005).

\section{Subjek penelitian}

Subjek dalam penelitian ini adalah pasien gagal ginjal kronis, berjenis kelamin laki-laki dan perempuan. Subjek setidaknya telah menjalani hemodialisis minimal 6 bulan di Klinik Hemodialisis Nitipuran di Yogyakarta. Rentang usia subjek adalah berusia 20-50 tahun, memiliki optimisme kategori rendah dan sedang, dan bersedia berpartisispasi dalam penelitian. Pada kelompok eksperimen dan kelompok 
kontrol masing-masing terdiri atas empat orang.

\section{Metode pengumpulan data}

Metode pengumpulan data dilakukan dengan menggunakan satu skala, yaitu skala optimisme yang telah direvisi oleh Scheier, Carver, dan Bridges (1994) yang disebut dengan LOT-R (Life Orientation Test-Revised). Alat ukur ini telah digunakan dalam dua penelitian sebelumnya, yaitu Millah (2016) dan Amanah (2016) yang dilakukan kepada pasien diabetes melitus dan pasien gagal ginjal kronik. Hasil reliabilitas skala LOT-R sebesar 0,736 (Amanah, 2016) dan 0,748 (Millah, 2016). Skala optimisme ini terdiri dari tiga item positif (favorable), tiga item negatif (unfavorable), dan empat item pengalih (Scheier, Carver, dan Bridges, 1994).

\section{Prosedur Intervensi}

Intervensi yang diberikan dalam penelitian ini adalah terapi kelompok suportif yang disusun berdasarkan teori kelompok suportif van den Heuvel, dkk. (2002). Teori ini telah digunakan dalam modul intervensi terapi kelompok suportif pada penelitian sebelumnya, yaitu pada penelitian Kurniawan (2015), Jariyah (2016), dan Andaryati (2017). Penelitian ini memodifikasi modul intervensi tersebut pada bagian alokasi waktu dan adanya kegiatan ice-breaking.

Penelitian ini dilakukan dengan tiga kali pertemuan dan sekali tindak lanjut. Pertemuan pertama berdurasi 120 menit, pertemuan kedua berdurasi 120 menit, pertemuan ketiga berdurasi 120 menit, serta dilakukan pengukuran tindak lanjut setelah \pm 10 -14 hari pertemuan terakhir.

\section{Metode analisis data}

Metode analisis data yang digunakan dalam penelitian ini adalah uji Mann Whitney. Uji analisis tersebut digunakan untuk membantu peneliti dalam membedakan hasil kinerja kelompok yang terdapat dalam sampel ke dalam dua kelompok dengan dua kriteria yang berbeda. Analisis data ini dilakukan menggunakan program Statistical Program for Science (SPSS) for Windows versi 22.0.

\section{HASIL PENELITIAN}

Hasil uji hipotesis penelitian ini menunjukkan bahwa terdapat pengaruh yang signifikan dari terapi kelompok suportif untuk meningkatkan optimisme pasien gagal ginjak kronis yang menjalani hemodialisis pada subjek kelompok eksperimen dibandingkan subjek kelompok kontrol yang tidak mendapatkan intervensi dengan $\mathrm{Z}=-2,32$ dan nilai $\mathrm{p}=0,00(\mathrm{p}<$ $0,005)$. 
Tabel 1. Analisis kuantitatif dan diagram

\begin{tabular}{|c|c|c|c|c|}
\hline \multicolumn{5}{|c|}{ Deskripsi data statistik } \\
\hline \multirow[t]{2}{*}{ Pengukuran } & \multicolumn{2}{|c|}{ Kelompok eksperimen } & \multicolumn{2}{|c|}{ Kelompok kontrol } \\
\hline & Mean & SD & Mean & SD \\
\hline Pra-uji & 20,50 & 2,082 & 19,50 & 1,29 \\
\hline Pasca-uji & 27,75 & 2,217 & 20,75 & 0,95 \\
\hline Tindak lanjut & 27,75 & 1,500 & 21,25 & 0,95 \\
\hline \multicolumn{5}{|c|}{ Uji beda skor optimisme antara kelompok ekperimen dan kelompok kontrol } \\
\hline Pengukuran & \multicolumn{2}{|c|}{$\mathrm{Z}$} & \multicolumn{2}{|c|}{$p$} \\
\hline Pra-uji & \multicolumn{2}{|c|}{$-0,73$} & \multicolumn{2}{|c|}{5,50} \\
\hline Pasca-uji & \multicolumn{2}{|c|}{$-2,32$} & \multicolumn{2}{|c|}{0,00} \\
\hline Tindak lanjut & \multicolumn{2}{|c|}{$-2,33$} & \multicolumn{2}{|c|}{0,00} \\
\hline \multicolumn{5}{|c|}{ Uji beda skor optimisme pada masing-masing kelompok } \\
\hline \multirow[t]{2}{*}{ Pengukuran } & \multicolumn{2}{|c|}{ Kelompok eksperimen } & \multicolumn{2}{|c|}{ Kelompok kontrol } \\
\hline & $\mathrm{t}$ & $\mathrm{p}$ & $\mathrm{t}$ & $\mathrm{p}$ \\
\hline Pra-uji ke pasca-uji & $-10,72$ & 0,02 & $-2,61$ & 0,80 \\
\hline Pasca-uji ke tindak lanjut & $-0,77$ & 0.49 & $-0,52$ & 0,63 \\
\hline Pra-uji ke tindak lanjut & $-3,97$ & 0,00 & $-1,69$ & 0,18 \\
\hline
\end{tabular}

Berdasarkan tabel analisis kuantitatif dan diagram, dapat dilihat bahwa skor optimisme mengalami peningkatan setelah mengikuti terapi kelompok suportif dari pengukuran pra-uji (mean $=20,50 ; S D=$ 2,082) dan pada pengukuran pasca-uji $($ mean $=27,75 ; S D=2,217)$. Walaupun begitu, pada pengukuran tindak lanjut, tidak terdapat peningkatan yang signifikan pada kelompok eksperimen. Pada kelompok kontrol, peningkatan setelah mengikuti terapi kolompok suportif dari pengukuran pra-uji (mean $=19,50 ; S D=1,291)$ dan pada pengukuran pasca-uji (mean $=20,75 ; S D=$ $0,957)$. Namun, pada pengukuran tindak lanjut, tidak terdapat peningkatan yang signifikan pada kelompok kontrol.

Selain itu, berdasarkan hasil uji hipotesis yang dilakukan, terdapat perbedaan skor optimisme yang signifikan pada pasien gagal ginjal yang menjalani hemodialisis setelah diberikan terapi kelompok suportif dibandingkan dengan kelompok kontrol atau hipotesis diterima dengan nilai $\mathrm{Z}=-2,323$ dan $p=0,00(\mathrm{p}<$ $0,05)$. Lebih lanjut, perbedaan skor optimisme yang signifikan juga ditemukan pada kondisi tindak lanjut selama dua minggu intervensi dilakukan dengan nilai $\mathrm{Z}$ $=-2,337$ dan $p=0,00(\mathrm{p}<0,05)$.

Uji beda juga dilakukan pada perbedaan kondisi pengukuran pada masing-masing kelompok. Pada kelompok eksperimen, terdapat perbedaan skor yang signifikan pada kondisi pengukuran pra-uji ke pascauji $(p=0,02 ; \mathrm{t}=-10,729)$ dan pasca-uji ke tindak lanjut ( $p=0,495 ; \mathrm{t}=-0,775)$. Namun, tidak terdapat perbedaan skor optimisme yang signifikan pada kondisi pra-uji - tindak lanjut. Pada kelompok kontrol, tidak terlihat perbedaan skor optimisme yang signifikan pada kondisi pengukuran pra-uji - pasca-uji.

\section{PEMBAHASAN}

Tujuan penelitian ini adalah meningkatkan optimisme pasien gagal ginjal kronis yang menjalani hemodialisis melalui terapi kelompok suportif. Berdasarkan hasil penelitian, hipotesis yang diajukan dalam penelitian ini diterima, yaitu terdapat pengaruh terapi kelompok suportif dalam meningkatkan optimisme pada penderita 
gagal ginjal kronis yang menjalani hemodialisis. Kelompok eksperimen yang diberi perlakuan memiliki skor optimisme lebih tinggi dibandingkan dengan kelompok kontrol yang tidak diberi perlakuan, baik secara nilai rerata maupun individu pada masing-masing kelompok.

Hasil dari temuan penelitian ini didukung dengan pernyataan Finck, dkk. (2018) bahwa dukungan sosial merupakan prediktor dan sumber optimisme pada individu yang sedang menghadapi kesulitan atau berasa pada kondisi stres akibat menderita kanker payudara. Dukungan dari lingkungan terdekat pasien, seperti orangtua, pasangan, bahkan dokter dan perawat mampu membuat pasien merasa didukung dan tidak sendiri, sehingga pasien merasa dapat menghadapi kesulitannya dan memiliki pandangan yang lebih positif terhadap masa depannya (Finck, dkk., 2018). Wardiyah, Afiyanti dan Budiati (2014) menyebutkan bahwa dukungan sosial adalah faktor dominan yang mempengaruhi optimisme kesembuhan pasien kanker payudara karena dirasa dapat menurunkan tekanan psikologis, rasa sedih, dan meningkatkan semangat serta harapan mereka terhadap kondisinya. Temuan dalam penelitian ini juga sejalan dengan temuan penelitian Tabrizi, Radfar dan Taei (2016) yang menemukan bahwa intervensi dengan pendekatan kelompok dapat meningkatkan harapan atau optimisme individu yang menderita penyakit kronis atau sedang menjalani pengobatan secara umum seperti kanker karena selama proses terapi kelompok, para pasien dapat mengekspresikan pikiran dan perasaannya secara terbuka dan lebih nyaman kepada para pasien lainnya yang juga menderita penyakit yang sama.

Perubahan optimisme pada subjek dapat dipengaruhi oleh proses saling mendukung dan apresiasi yang terjadi selama terapi kelompok suportif. Para subjek saling memberikan masukan, saran dan apresiasi terhadap pendapat subjek lain. Sering pula subjek saling memberikan tepuk tangan, senyuman atau pujian sehingga subjek dapat merasa diterima, dihargai dan didukung oleh orang lain. Applebaum, dkk. (2014) mengungkapkan bahwa dukungan sosial dari orang lain dalam segala bentuk, seperti pujian, apresiasi bahkan dukungan finansial yang diberikan orang lain kepada individu dengan penyakit kronis dapat menurunkan tekanan psikologisnya dan juga meningkatkan pandangan positif terhadap dirinya.

Terapi kelompok suportif mampu memberikan ruang dan kesempatan bagi individu untuk menyampaikan emosi dan perasaannya kepada anggota kelompok lain dengan leluasa serta mendapatkan umpan balik dari anggota kelompok tersebut. Hal ini didukung dengan penelitian Dowlatabadi, dkk. (2016) yang mengungkapkan bahwa proses katarsis dengan orang lain selama menjalani proses terapi kelompok dapat mengurangi emosi-emosi negatif yang muncul pada pasien dengan penyakit kronis, sehingga individu dapat merasa memiliki dukungan dan memandang hidupnya lebih positif lagi.

Berbagi dengan peserta lain dalam satu kelompok efektif dalam meningkatkan perasaan dan pola pikir yang lebih positif bagi individu dengan penyakit kronis (Zamaniyan, dkk., 2016). Hal ini didukung oleh penelitian Levi, dkk (2017), yaitu terapi kelompok suportif bermanfaat dalam meningkatkan harapan individu yang mengalami stres pascatrauma. Para anggota kelompok berperan sebagai penampung emosi negatif sekaligus penyemangat bagi mereka (Levi, dkk., 2017).

Selain itu, meningkatnya optimisme subjek terhadap masa depan melalui kelompok suportif ini juga dipengaruhi oleh adanya respon verbal dan non-verbal yang diberikan peserta lain kepada subjek yang 
telah mau berbagi atau sedang bercerita. Respon verbal yang diberikan, misalnya kalimat pujian, apresiasi, saran dan alternatif solusi yang dapat peserta lakukan. Respon non-verbal ini terlihat dalam bentuk anggukan, senyuman, dan aktif mendengarkan dengan tidak memotong pembicaraan lawan bicara. Adanya respon verbal dan non-verbal ini membuat subjek merasa diterima dan dihargai karena adanya rasa empati yang ditunjukkan subjek melalui respon verbal dan non-verbal tersebut.

Hal tersebut sesuai dengan penelitian Thompson, dkk. (2014) mengenai pengaruh terapi kelompok suportif terhadap harapan dan kesejahteraan psikologis pasien kanker payudara. Hasil penelitian tersebut menunjukkan bahwa respon non-verbal dari teman-teman satu kelompok, seperti memperhatikan pembicaraan, mendengarkan, bahkan memeluk, membuat peserta merasa dikuatkan dan diterima, sehingga pada akhirnya mampu membuat para peserta memiliki pandangan terhadap masa depan yang lebih positif (Thompson, dkk., 2014). Kauff (2017) menambahkan bahwa dukungan yang diperoleh dari kelompok suportif dalam bentuk verbal dan non-verbal merupakan bentuk afirmasi atau penguatan yang diberikan para peserta kelompok kepada satu sama lainnya, sehingga membuat para peserta lebih nyaman ketika berbagi mengenai perasaan dan pikiran yang negatif kepada anggota kelompoknya.

\section{KESIMPULAN DAN SARAN}

\section{Kesimpulan}

Berdasarkan hasil penelitian dapat disimpulkan bahwa terdapat perbedaan skor optimisme yang signifikan antara pasien gagal ginjal yang menjalani hemodialisis pada kelompok eksperimen setelah mengikuti terapi kelompok suportif dibandingkan dengan kelompok kontrol. Adapun perubahan positif juga dirasakan para subjek dalam kelompok eksperimen, baik secara psikologis maupun sosial.

\section{Saran}

Bagi subjek penelitian, pada masa depan diharapkan mampu menerapkan hasil diskusi dan berbagi pengalaman selama terapi kelompok suportif. Diharapkan, dengan menerapkan hasil diskusi yang diperoleh, dapat menguatkan kondisi psikologis subjek. Para peserta juga diharapkan dapat tetap aktif menjalin komunikasi yang dilakukan secara langsung melalui pertemuan, maupun komunikasi secara tidak langsung melalui media sosial.

Bagi pengelola atau pengurus Klinik Hemodialisis, diharapkan mampu memberikan pelayanan atau pendampingan psikologis kepada pasien, mengingat permasalahan psikologis yang dirasakan oleh pasien dapat menghambat proses pengobatan yang dilakukan. Pendampingan psikologis ini dapat berupa adanya kerja sama antara klinik dengan rumah sakit atau puskesmas terdekat yang memiliki layanan psikologi, sehingga memungkinkan untuk mengadakan pertemuan secara lebih rutin. 


\section{DAFTAR PUSTAKA}

Amanah, S. (2016). Hubungan antara optimisme dengan kualitas hidup pada pasien gagal ginjal kronis yang menjalani hemodialisa. (Skripsi, tidak diterbitkan). Universitas Islam Indonesia, Yogyakarta, Indonesia.

Andaryati,A., Uyun, Q., \& Sulistyarini, I. (2017). Terapi kelompok dukungan untuk meningkatkan resiliensi pasien gagal ginjal kronik yang menjalani hemodialisa. (Tesis, tidak diterbitkan). Universitas Islam Indonesia, Yogyakarta, Indonesia.

Applebaum, A. J., Stein, E. M., Lord-Bessen, J., Pessin, H., Rosenfeld, B., \& Breitbart, W. (2014). Optimism, social support, and mental health outcomes in patients with advanced cancer: Optimism, social support, and advanced cancer. PsychoOncology, 23(3), 299-306.

Brabender, V.A., Fallon, A.E., \& Smolar, A.I. (2004). Essential of group therapy. New Jersey: John Wiley \& Sons, Inc.

Carver, C.S., Scheier, M.F., \& Segerstrom, S.C. (2010). Optimism. Clinical Psychology Review, 30, 879-889.

Carver, C. S., dan Scheier, M. F. (2001). Optimism and pessimism: Implications for theory, research and practice. Washington, DC: American Psychological Association.

Chang, E. C. (2009). An examination of optimism, pessimism, and performance perfectionism as predictors of positive psychological functioning in middle-aged adults: Does holding high standards of performance matter beyond generalized outcome expectancies? Cognitive Therapy and Research, 33(3), 334-344.
Chang, E., Daly, J., \& Elliott D. (2010). Patofisiologi aplikasi pada praktik keperawatan. Jakarta: Buku Kedokteran EGC.

Corey, G. (2010). Theory and practice of group counselling (8th edition). Belmont, CA, USA: Brooks/Cole, Cengage Learning

Daraei, M., \& Ghaderi, A. R. (2012). Impact of education on optimism/pessimism. Journal of the Indian Academy of Applied Psychology, 38(2), 339-343

Dowlatabadi, M. M., Ahmadi, S. M., Sorbi, M. H., Beiki, O., Razavi, T. K., \& Bidaki, R. (2016). The effectiveness of group positive psychotherapy on depression and happiness in breast cancer patients: a randomized controlled trial. Electronic Physician, vol 8 (3):2175-80.

Finck, C., Barradas, S., Zenger, M., \& Hinz, A. (2018). Quality of life in breast cancer patients : Associations with optimism and social support. International Journal of Clinical and Health Psychology, 18(1), 27-34.

Gillham, J. E., Shatté, A. J., Reivich, K. J., \& Seligman, M. E. P. (2001). Optimism, pessimism, and explanatory style. In E. C. Chang (Ed.), Optimism \& pessimism: Implications for theory, research, and practice (pp. 53-75). Washington, DC, American Psychological Association.

van den Heuvel, E. T., Witte, L. P., Stewart, R. E., Schure, L. M., Sanderman, R., Meyboom-de Jong, B. (2002). Longterm Effect of A Group Support Program and An Individual Support Program for Informal Caregivers of Stroke Patients: Which Caregivers Benefit Most? Journal of Patient Education and Counseling, 47, 291-299. 
Indonesian Renal Registry (IRR). (2016). 7th Report of Indonesian renal registry. Diunduh pada 15 November 2018, dari: https://www.indonesianrenalregistry. org/data/INDONESIAN\%20RENAL\%2 0REGISTRY\%202014.pdf.

Jariyah, S. (2016). Terapi kelompok dukungan untuk meningkatkan penerimaan orang tua yang anaknya autis. (Tesis tidak diterbitkan). Fakultas Psikologi dan Ilmu Sosial Budaya, Universitas Islam Indonesia, Yogyakarta, Indonesia.

Kurniawan, Y. (2015). Terapi kelompok pendukung pada orang tua pasien talassemia. (Tesis tidak diterbitkan). Fakultas Psikologi dan Ilmu Sosial Budaya, Universitas Islam Indonesia, Yogyakarta, Indonesia.

Kauff, P. F. (2017). Psychoanalytic Group Psychotherapy. International Journal of Group Psychotherapy. 67(1), 91-98.

Levi, O., Shoval-zuckerman, Y., Fruchter, E., Bibi, A., Bar-haim, Y., Wald, I., \& Force, I. D. (2017). Benefits of a Psychodynamic Group Therapy (PGT) Model for Treating Veterans With PTSD. Journal of Clinical Psychology, 73(10), 1247-1258.

Millah, F. N. (2016). Hubungan antara optimisme dengan kualitas hidup pada pasien diabetes melitus. (Skripsi tidak diterbitkan). Universitas Islam Indonesia, Yogyakarta, Indonesia.
National Kidney Disease Education Program (NKDEP). (2014). Chronic kidney disease and diet: assesment management and treatment. Diunduh pada 12 Oktober 2018, dari: https://www.niddk.nih.gov//media/Files/HealthInformation/CommunicationPrograms/NKDEP/ckd-diet-assessmanage-treat-508.pdf

Pender, N. J., Murdaugh, C. L., \& Parsons, M. A. (2002). Health promotion in nursing practice. (4th ed.). New Jersey: Pearson.

Price, S. A. (2006). Patofisiologi Konsep Klinis Proses-proses Penyakit. Jakarta: Kedokteran EGC.

Rajandram, R. K., Ho, S. M., Samman, N., Chan, N., McGrath, C., \& Zwahlen, R. A. (2011). Interaction of hope and optimism with anxiety and depression in a specific group of cancer survivors: A preliminary study. BMC Research Notes, 4(1), 519-519.

Rahman, A.R., Rudiansyah, M., \& Triawanti, T. (2013). Hubungan antara adekuasi hemodialisis dan kualitas hidup pasien di RSUD Ulin Banjarmasin. Berkala Kedokteran. 9(2), 151-160.

Safitri, A. H., \& Dewi, D. S. E. (2014). Deskripsi tingkat harapan pada penderita gagal ginjal kronik di RSU Prof Dr. Margono Soekarjo Purwokerto. Psycho Idea. 12(1), 47-53.

Sarafino, E.P. (2002). Health psychology biopsychological interaction, 2nd edition. New John Wiley and Sons 
Sari, R. (2009). Dukungan sosial pada pasien kanker payudara di masa dewasa tengah. (Skripsi, tidak diterbitkan). Universitas Gunadarma, Jakarta, Indonesia.

Scheier, M. F., \& Carver, C. S.(1985). Optimism, coping, and health: assessment and implication of generalized outcome expectancies. Health Psychology. 4(3), 219-247

Seidel, U. K., Gronewold, J., Volsek, M., Todica, O., Kribben, A., Bruck, H., \& Hermann, D. M. (2014). Physical, cognitive and emotional factors contributing to quality of life, functional health and participation in community dwelling in chronic kidney disease. PLoS One, 9(3): e91176

Seligman, M. E. P. (2006). Learned optimism: how to change your mind and your life. New York: Vintage Books.

Sukardi. (2005). Metodelogi penelitian pendidikan, kompetensi dan prakteknya. Jakarta: Bumi Aksara.

Tabrizi, F. M., Radfar, M., Taei, Z., F.M., T., \& M., R. (2016). Effects of supportiveexpressive discussion groups on loneliness, hope and quality of life in breast cancer survivors: a randomized control trial. Psycho-Oncology. 25(9), 1057-1063.
Thompson, J., Coleman, R., Colwell, B., Freeman, J., Green, D., Holmes, K., ... Reed, M. (2014). Preparing breast cancer patients for survivorship: A pilot study of a patient-centred supportive group visit intervention. European Journal of Oncology Nursing. 18(1), 1016.

Videbeck, S. L. (2008). Buku ajar keperawatan jiwa. Jakarta: EGC.

Wardiyah, A., Afiyanti, Y., dan Tri Budiati. (2014) Faktor yang mempengaruhi optimisme kesembuhan pada pasien kanker payudara. Jurnal Keperawatan. 5(2), 121-127.

Yulianti, R., Rochmawati, D., dan Purnomo. (2015). Pengaruh cognitive therapy pada pasien gagal ginjal kronis di SMC RS Telogorejo. Jurnal Ilmu Keperawatan dan Kebidanan (JIKK). 2 (3), 123-133.

Zamaniyan, S., Bolhari, J., Naziri, G., Akrami, M., \& Hosseini, S. (2016). Effectiveness of Spiritual Group Therapy on Quality of Life and Spiritual Well-Being among Patients with Breast Cancer. Iranian journal of medical sciences. 41 (2), 140-144. 
Salma Dias Saraswati, Yayi Suryo Prabandari \& Rr. Indahria Sulistyarini 